\title{
DETEKSI URUTAN OLIGONUKLEOTIDA Mycobacterium tuberculosis SECARA VOLTAMMETRI MENGGUNAKAN SCREEN PRINTED CARBON ELECTRODE (SPCE)
}

\author{
Yeni Wahyuni Hartati, Yohan, Ratna Nurmalasari, Shabarni Gaffar, Rubianto A. Lubis \\ Departmen Kimia, Fakultas Matematika dan Ilmu Pengetahuan Alam, Universitas Padjadjaran, 45363 \\ Jatinangor, Jawa Barat, Indonesia \\ *Alamat Korespondensi: yeni.w.hartati@unpad.ac.id
}

\begin{abstract}
Abstrak: Mycobacterium tuberculosis merupakan bakteri penyebab tuberkulosis (TB). Pengembangan analisis secara biosensor DNA sangat menarik perhatian karena penerapannya mudah. Dalam penelitian ini telah dilakukan penentuan urutan pendek oligonukleotida $M$. tuberculosis gen RV0508 dari strain H37RV secara voltammetri pulsa differensial menggunakan screen printed carbon electrode (SPCE). Pendeteksian berdasarkan teknik hibridisasi urutan oligonukleotida probe yang diadsorpsi pada permukaan SPCE, dengan pasangan komplementernya dari DNA target, tanpa indikator hibridisasi, yaitu dengan mensubstitusi basa guanin probe dengan basa inosin. Respon hibridisasi berupa signal guanin DNA target di daerah potensial sekitar $+0,9 \mathrm{~V}$. Telah diperoleh korelasi linear antara arus puncak dengan konsentrasi DNA target pada rentang 5,0-20,0 $\mu \mathrm{g} / \mathrm{mL}$ dengan batas deteksi $8,2 \mu \mathrm{g} / \mathrm{mL}$.
\end{abstract}

Kata kunci: $M$. tuberculosis, SPCE, biosensor DNA, voltammetri

Abstract: Mycobacterium tuberculosis is the bacterium that causes tuberculosis (TB). Development of DNA biosensor analysis is very interesting because its application is easy. In this research has done the determination of short oligonucleotide sequences M. tuberculosis RV0508 gene of the strains H37RV by differential pulse voltammetric methods using screen printed carbon electrodes (SPCE). Detection based on hybridization of oligonucleotide probe sequences are adsorbed on the surface of SPCE, with its complementary pair of target DNA, without hybridization indicator, by substituting guanine base with inosine of probe. Response of hybridization was found as a signal of the target DNA guanine in the area of a potential of about $+0.9 \mathrm{~V}$. The linear correlation between peak current with the target DNA concentration was achieved in the range of $5.0-20.0 \mu \mathrm{g} / \mathrm{mL}$ with a detection limit of $8.2 \mu \mathrm{g} / \mathrm{mL}$.

Keywords: M. tuberculosis, SPCE, DNA biosensor, voltammetry

\section{PENDAHULUAN}

Tuberkulosis (TB) merupakan penyakit penyebab kematian dan menduduki posisi kedua setelah HIV banyak terjadi terutama di negara berkembang (Hamdan et al. 2012; Zhou 2011). Oleh karena itu, diagnosis secara langsung, sederhana, sensitif dan spesifik dapat membantu untuk mengisolasi pasien dan mengontrol penyakit tersebut.

Beberapa metode analisis yang telah dikembangkan untuk diagnosis bakteri $M$. tuberculosis yaitu metode tuberculosis skin test, berdasarkan pemurnian protein derivatif (Reyes et al. 2011; Stavri et al. 2004), kultur bakteri, radioimmunoassay (Kardival et al. 2000), polymerase chain reaction (PCR), real time PCR, ELISA (Abdelwahab 2010), piezoelectric (Kaewphinit et al. 2010), mikroskopi, multi-antigen print immunoassay, mikrokantilever berdasarkan kit diagnostik (Sangeetha et al. 2014). Berbagai jenis masalah yang dihadapi dalam melakukan diagnosis TB dalam sampel klinis, dua diantaranya adalah penggunaan senyawa kimia berbahaya seperti cahaya UV dan etidium bromida yang bersifat mutagen selama melakukan elektroforesis gel agarosa (pada saat karakterisasi amplikon PCR). Selain itu, penggunaan instrumen yang mahal seperti real time-PCR memerlukan keahlian khusus dalam pengoperasiannya, dan juga membutuhkan reagen kimia yang cukup mahal seperti pewarna hijau SYBR dan Taqman (Yean et al. 2008; Hamdan et al. 2012).

Di antara berbagai metode untuk deteksi DNA, teknik elektrokimia memiliki beberapa kelebihan seperti: sederhana, waktu analisis yang singkat, relatif murah, sensitivitas tinggi, dan cocok untuk pengembangan perangkat portabel (Jin et al. 2013), juga dapat mensubstitusi metode elektroforesis, sehingga tidak menggunakan senyawa karsinogenik. Selain itu, transduser elektrokimia telah banyak dikembangkan untuk mendeteksi terjadinya hibridisasi DNA, karena sensitivitasnya tinggi, dimensinya kecil, dan biayanya tidak mahal (Wang et al. 1997).

Telah dilakukan deteksi M. tuberculosis melalui biosensor DNA secara voltammetri pulsa diferensial dengan menggunakan elektrode emas melalui teknik self assembly monolayer (Nurmalasari et al. 2015). Penelitian lainnya dilakukan Hamdan et al. (2012) menggunakan elektrode grafit pensil dan metilen biru untuk mendeteksi $M$. tuberculosis secara biosensor elektrokimia. Pemilihan elektrode dalam metode voltammetri merupakan hal yang sangat penting. Salah satu elektrode yang menawarkan beberapa 
keuntungan yaitu ramah lingkungan, ukuran elektrode lebih kecil sehingga dapat dipasangkan dengan potensiostat yang portabel dan dapat dikembangkan menjadi miniaturisasi biosensor yaitu screen printed carbon electrode (SPCE). Penggunaan SPCE untuk deteksi M. tuberculosis telah dikembangkan dengan penggunaan indikator metilen biru (Issa et al. 2010). Dari hasil penelitian tersebut menunjukkan bahwa biosensor elektrokimia merupakan metode yang sederhana, sensitif dan ekonomis untuk mendeteksi M. tuberculosis.

Dalam penelitian ini, kami melakukan deteksi $M$. tuberculosis menggunakan SPCE dengan teknik deteksi hibridisasi tanpa indikator, yaitu hanya mengamati elektroaktivitas intrinsik dari asam nukleat, yaitu dengan mengamati sinyal oksidasi dari basa guanin DNA target. Teknik ini tidak memerlukan waktu yang lama dalam pengerjaanya dan merupakan strategi deteksi hibridisasi yang lebih mudah diterapkan dibandingkan dengan teknik lainnya, seperti penggunaan indikator atau modifikasi-modifikasi lain untuk mendeteksi terjadinya hibridisasi.

\section{BAHAN DAN METODE Bahan}

Bahan yang digunakan dalam penelitian ini antara lain ssDNA probe (5'-IAC III CAA TCC AII IC-3') dimana basa guanin $(\mathrm{G})$ diganti dengan basa inosin (I), ssDNA target (5'- GCC CTG GAT TGC CCG TC -3'), ssDNA non komplementer (5'-GAG CTG TGA AAT TTG GTG CC-3') (First base, Singapore). Urutan DNA probe dan target ini dirancang berdasarkan strain H37RV gen Rv0508 dalam $M$. tuberculosis. ssDNA larutan stok $(100 \mu \mathrm{g} / \mathrm{mL})$ dilarutkan dengan larutan bufer asetat $0,5 \mathrm{M} \mathrm{pH} \mathrm{5,0}$ mengandung $0,02 \mathrm{M} \mathrm{NaCl}$, bufer fosfat $0,1 \mathrm{M} \mathrm{pH}$ 7,0 , akuabides, dan pure $\mathrm{H}_{2} \mathrm{O}$ grade PCR.

\begin{abstract}
Alat
Alat-alat yang digunakan dalam penelitian ini antara lain Voltammetri Diffensial Pulsa (VDP) dilakukan dengan menggunakan Metrohm ${ }^{\circledR} \mu$ Autolab tipe III potensiostat terhubung ke PC dilengkapi dengan software NOVA 1.7. Sel elektrokimia sistem tiga-elektrode terdiri dari elektrode kerja SPCE (Dropsens), elektrode referensi $\mathrm{Ag} / \mathrm{AgCl} \mathrm{KCl} 3,0 \mathrm{M}$ dan elektrode bantu platina. autoclave, $\mathrm{pH}$ meter, biophotometer plus Eppendorf ${ }^{\circledR}$, oven, pipet mikro, sentrifugasi, avometer YX-360 TR, sonikator, tabung mikro, tip pipet, vortex, dan alat-alat gelas yang umum digunakan di laboratorium.
\end{abstract}

\section{Karakterisasi SPCE Secara Voltammetri Siklik}

Elektrode di-pretreatment dengan cara diberikan potensial $+1,4 \mathrm{~V}$ selama 1 menit dan dikeringkan beberapa menit, kemudian dicuci dengan aquabides. Untuk karakterisasi elektrode; ditetesi larutan 0,01 M $\mathrm{K}_{4}\left[\mathrm{Fe}(\mathrm{CN})_{6}\right] / 0,1 \mathrm{M} \mathrm{KCl}$ pada suhu ruang $\left(25^{\circ} \mathrm{C}\right)$ dan dipindai pada potensial -0,8 sampai $0,6 \mathrm{~V}$.

\section{Amobilisasi ssDNA probe}

Elektrode yang telah di-pretreatment kemudian ditetesi $20 \mu \mathrm{L}$ ssDNA probe yang dilarutkan dalam buffer asetat 0,5 $\mathrm{M}$ pH 5,0 mengandung $\mathrm{NaCl} 0,02$ M. Waktu amobilisasi dan konsentrasi divariasikan untuk mendapatkan pengukuran optimal. Semua pengkuran dilakukan pada suhu ruang $\left(25^{\circ} \mathrm{C}\right)$.

\section{Hibridisasi Probe-Target Sintesis dan Kurva Standar}

Elektrode yang telah diamobilisasi dengan ssDNA probe pada permukaan elektrode dibilas dengan buffer asetat $0,5 \mathrm{M} \mathrm{pH}$ 5,0 mengandung $\mathrm{NaCl}$ 0,02 M, dan kemudian elektrode ditetesi dengan ssDNA target sintesis berbagai variasi konsentrasi. Variasi waktu hibridisasi juga dilakukan, dan semua pengerjaan dilakukan pada suhu ruang $\left(25^{\circ} \mathrm{C}\right)$.

\section{HASIL DAN PEMBAHASAN}

Karakterisasi SPCE Secara Voltammetri Siklik

Untuk mempelajari sifat permukaan SPCE dilakukan secara voltammetri siklik (Bard \& Faulkner, 2000), dengan mengamati aktivitas reduksi-oksidasi dari spesi elektroaktif seperti $\left[\mathrm{Fe}(\mathrm{CN})_{6}\right]^{3-}$ dengan tiga kali pengulangan. Pemindaian diterapkan pada potensial $-0,8 \mathrm{~V}$ sampai $+0,6 \mathrm{~V}$, dengan laju pindai $50 \mathrm{mV} / \mathrm{s}$. Gambar 1 memperlihatkan voltammogram siklis dari SPCE ditetesi $10 \mathrm{mM} \mathrm{K}_{3} \mathrm{Fe}(\mathrm{CN})_{6}$ yang mengandung $0,1 \mathrm{M}$ $\mathrm{KCl}$. Puncak oksidasi dan reduksi dari pengukuran tiga kali $\left[\mathrm{Fe}(\mathrm{CN})_{6}\right]^{3-}$ selalu tetap yaitu berturut-turut pada daerah sekitar $+0,3 \mathrm{~V}$ dan $-0,15 \mathrm{~V}$ vs $\mathrm{Ag} / \mathrm{AgCl}$. Hal ini menunjukkan SPCE memberikan reprodusibilitas yang baik. Sedangkan SPCE ditetesi buffer asetat $0,1 \mathrm{M} \mathrm{pH} \mathrm{5,0} \mathrm{yang} \mathrm{digunakan} \mathrm{sebagai}$ larutan blanko tidak memberikan puncak oksidasi dan reduksi pada rentang $-0,8 \mathrm{~V}$ sampai dengan $+0,6$ V.

\section{Optimasi pengukuran}

Pada penelitian ini pengamatan dilakukan pada signal hibridisasi DNA probe-target yang berupa oksidasi guanin melalui metode voltammetri pulsa diferensial. Arus puncak oksidasi guanin menggunakan elektrode grafit dapat diamati pada daerah potensial sekitar $0,9 \mathrm{~V}$ vs $\mathrm{Ag} / \mathrm{AgCl}(\mathrm{KCl} 3,0$ M) (Hartati et al. 2016).

DNA probe diamobilisai pada permukaan SPCE secara adsorpsi sederhana, dengan waktu amobilisasi yang dioptimasi. Demikian pula halnya dengan banyaknya konsentrasi DNA probe yang diamobilisasi, dan waktu hibridisasi probe-target, juga dioptimasi. Hasil optimasi ditunjukan pada Gambar 2.

Adsorpsi merupakan metode amobilisasi yang sangat sederhana dimana DNA probe dapat diikat tanpa ada modifikasi probe dengan molekul lain. Semakin maksimal probe teradsorbsi maka semakin meningkat signal namun pada batas tertentu semakin banyak DNA probe yang terdeposisi juga 


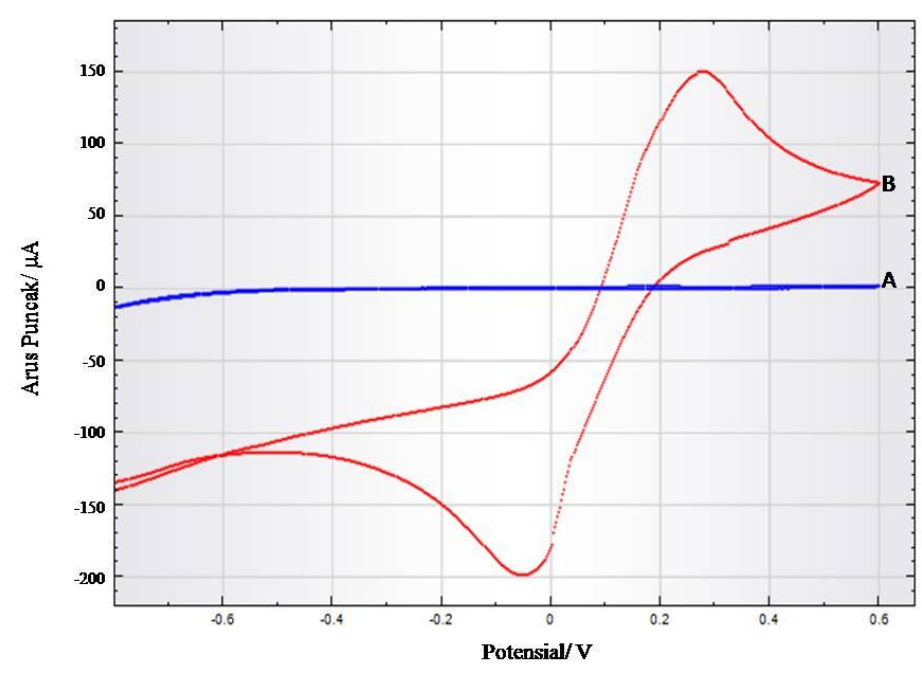

Gambar 1. Voltammogram siklis (A) SPCE dengan buffer asetat $0,1 \mathrm{M} \mathrm{pH} 5,0$; (B) SPCE dalam $0,01 \mathrm{M}$ $\mathrm{K}_{3} \mathrm{Fe}(\mathrm{CN})_{6}$ yang mengandung $0,1 \mathrm{M} \mathrm{KCl}$. Laju pemindaian $50 \mathrm{mV} / \mathrm{s}$.

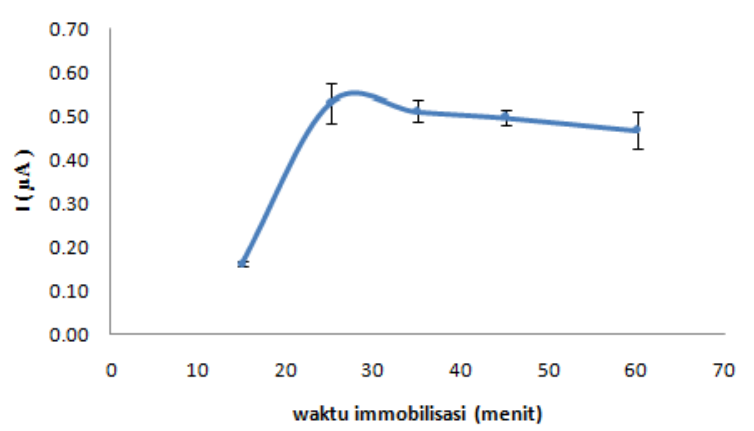

(A)

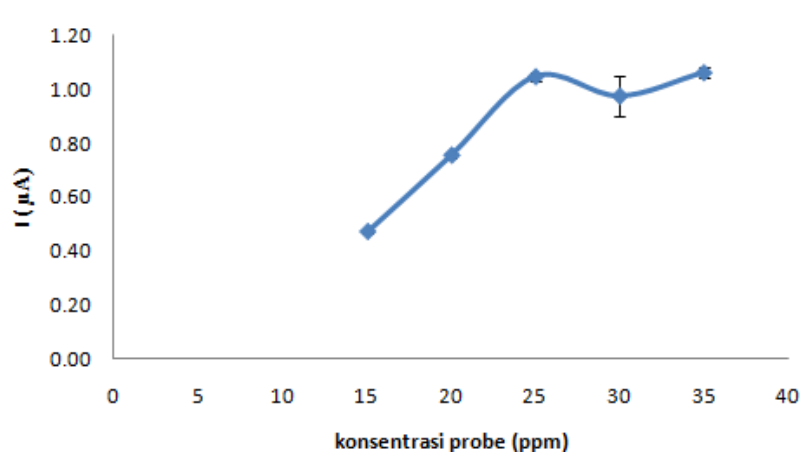

(B)

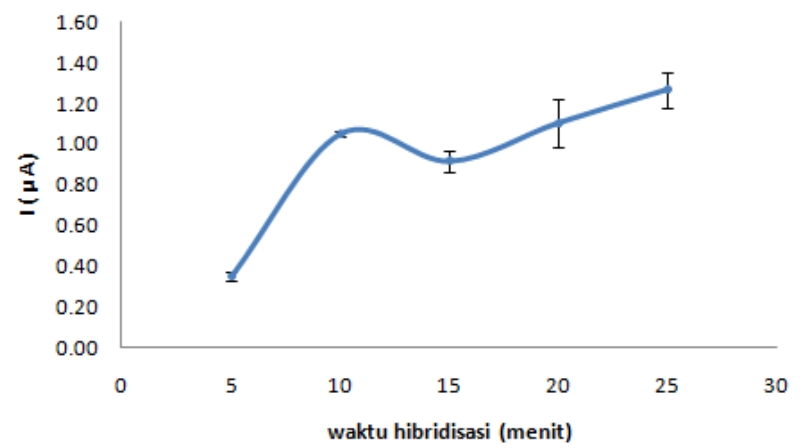

(C)

Gambar 2. Optimasi sinyal guanin dalam larutan bufer asetat $0,5 \mathrm{M} \mathrm{pH} 5,0$, (A). Pengaruh waktu amobilisasi terhadap signal guanin, (B). Pengaruh konsentrasi DNA probe (C). Pengaruh waktu hibridisasi DNA probetarget

memperkecil signal guanin, dimungkinkan karena terjadi penumpukan dan interaksi sesama DNA probe yang menutupi permukaan elektrode. Maka penting untuk melakukan pencucian dengan pelarutnya dan menemukan waktu yang sesuai untuk memperkuat signal guanin.

Pengaruh waktu terhadap amobilisasi pada penelitian ini dilakukan pada konsentrasi DNA probe
$10 \mu \mathrm{g} / \mathrm{mL}$, DNA target $25 \mu \mathrm{g} / \mathrm{mL}$, dan waktu hibridisasi selama 10 menit. Dari Gambar 2.A, dapat dilihat bahwa terjadinya peningkatan sinyal dengan variasi waktu amobilisasi dan hasil optimum amobilisasi dicapai pada waktu amobilisasi 25 menit. Waktu amobilisasi merupakan proses yang penting karena DNA memerlukan waktu untuk berikatan dengan karbon melalui adsorpsi. 


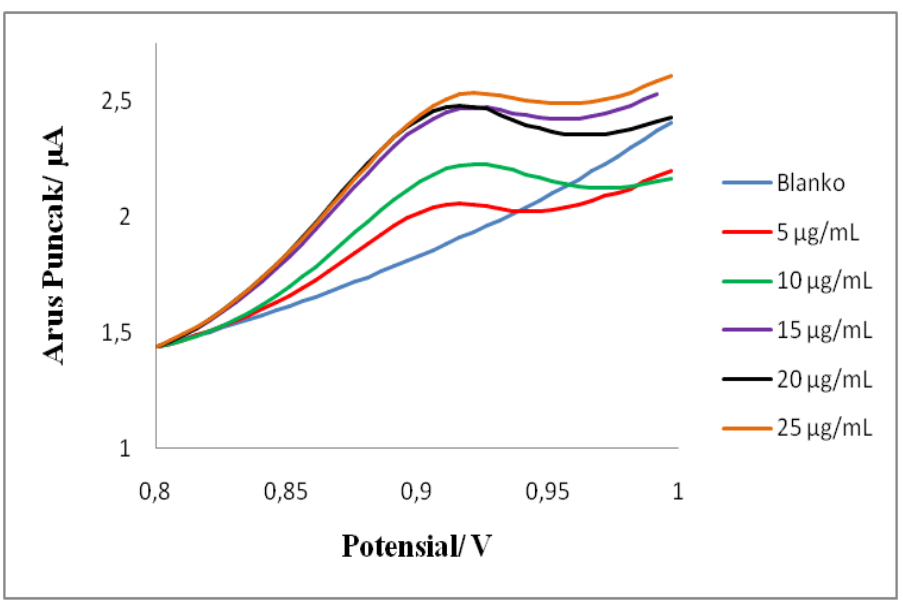

Gambar 3. Voltammogram DPV signal guanine target dari hasil hibridisasi DNA probe $25 \mu \mathrm{g} / \mathrm{mL}$ dengan DNA target $0,5,10,15,20$ dan $25 \mu \mathrm{g} / \mathrm{mL}$.

Penentuan konsentrasi probe optimum dilakukan dengan memvariasikan konsentrasi probe 15, 20, 25, 30 , dan $35 \mu \mathrm{g} / \mathrm{mL}$ dalam larutan buffer asetat $0,5 \mathrm{M}$ pH 5,0 yang mengandung $\mathrm{NaCl} 0,02 \mathrm{M}$. Gambar 2.B menunjukkan arus puncak mencapai $1,03 \mu \mathrm{A}$ pada konsentrasi probe $25 \mu \mathrm{g} / \mathrm{mL}$, dimana sebelumnya setiap peningkatan DNA probe $5 \mu \mathrm{g} / \mathrm{mL}$ mengalami kenaikan arus sekitar 0,28 $\mu \mathrm{A}$. Kemudian terjadi penurunan arus puncak pada konsentrasi $30 \mu \mathrm{g} / \mathrm{mL}$ menjadi $0,96 \mu \mathrm{A}$, dan pada konsentrasi $35 \mu \mathrm{g} / \mathrm{mL}$ terjadi kenaikan arus kembali pada nilai yang hampir sama untuk konsentrasi $25 \mu \mathrm{g} / \mathrm{mL}$. Hal ini kemungkinan disebabkan karena konsentrasi DNA probe pada permukaan SPCE sudah jenuh, sehingga penambahan konsentrasi yang semakin tinggi sudah tidak menyebabkan kenaikan arus yang lebih tinggi lagi. Untuk percobaan selanjutnya digunakan konsentrasi DNA probe $25 \mu \mathrm{g} / \mathrm{mL}$.

Gambar 2.C menunjukkan hasil percobaan optimasi waktu hibridisasi dilakukan vasiasi waktu yaitu 5, 10, 15, 20, dan 25 menit. Dari grafik terlihat waktu optimum ditunjukkan pada waktu hibridisasi 10 menit yang menghasilkan arus puncak $1,05 \mu \mathrm{A}$ terjadi peningkatan secara signifikan dibandingkan hibridisasi selama 5 menit.

\section{Kurva Kalibrasi dan Penentuan Batas Deteksi}

Dalam menentukan linieritas dan batas deteksi dibuat sederetan konsentrasi oligonukleotida target 0 $\mu \mathrm{g} / \mathrm{L}$ sampai $25 \mu \mathrm{g} / \mathrm{L}$ dalam larutan bufer fosfat 0,1 M pH 7,0. Voltamogram pulsa diferensial ditunjukkan pada Gambar 3, dimana dengan bertambahnya konsentrasi ssDNA target terjadi kenaikan arus puncak.

Linieritas konsentrasi oligonukleotida target dengan tinggi arus puncak dihasilkan pada rentang konsentrasi antara 5,0 sampai 20,0 $\mu \mathrm{g} / \mathrm{mL}$. Sedangkan konsentrasi oligonukleotida target 25 $\mu \mathrm{g} / \mathrm{mL}$ berada di luar persamaan garis, setelah dilakukan perhitungan uji-t. Hasil t-hitung 4,88, sedangkan $t$-tabel 3,18, maka konsentrasi $25 \mu \mathrm{g} / \mathrm{mL}$ tidak masuk ke dalam persamaan linieritas.

Persamaan garis untuk kurva kalibrasi diperoleh $\mathrm{Y}=0,0229 \mathrm{X}+0,0548$. Selanjutnya dihitung secara statistika untuk pengujian slope dan intersep pada taraf kepercayaan 95\%, diperoleh persamaan yang melewati titik nol, yaitu $\mathrm{Y}=0,027 \mathrm{X}$, dengan $\mathrm{R}^{2}=0,93$. Dari perhitungan diperoleh RSD $7,2 \%$, dan batas deteksi berdasarkan kurva kalibrasi diperoleh 8,2 $\mu \mathrm{g} / \mathrm{mL}$.

Issa et al. (2010) melakukan pendeteksian oligonukleotida $M$. tuberculosis dengan penggunaan indikator elektroaktif metilen biru melaporkan nilai RSD 8,61\%. Kelebihan tanpa penggunaan indikator terutama dalam mempersingkat waktu analisis dan pengamatan pada potensial intrinsik DNA target, tanpa mengamati daerah potensial oksidasi atau reduksi senyawa indicator elektroaktif.

\section{KESIMPULAN}

Proses deteksi oligonukleotida M. tuberculosis tanpa indikator hibridisasi ini didasarkan pada sinyal oksidasi guanin yang muncul pada potensial sekitar $+0,9$ V. Guanin pada untaian ssDNA probe diganti dengan inosin sehingga sensor akan memberikan arus puncak jika terhibridisasi dengan DNA target strain H37RV gen Rv0508.

\section{Ucapan Terima Kasih}

Penelitian ini didanai Hibah Penelitian Unggulan Perguruan Tinggi Unpad 2014.

\section{DAFTAR PUSTAKA}

Abdelwahab, A.E. (2010). Immunological and molecular diagnosis of Mycobacterium tuberculosis between two enviromentally different regions. Current Research in Tuberculosis. 1(1): 1-8.

Bard, A.J. \& Faulkner, L.R. (2000). Electrochemical Methods: Fundamentals and Applications. 2nd ed. John Wiley \& Sons, Inc. New York. 
Hamdan N.A., Issa, R., Noh, M.F.M. \& Zin, N. M. (2012). Electrochemical techique using methylene blue with pencil graphite electrode for optimum detection of Mycobacterium tuberculosis DNA. Current Research in Tuberculosis. 4(1): 1-12.

Hartati, Y.W., Wyantuti, S., Firdaus, M.L., Surbakti, R., Auliany, N., Gaffar, S. (2016). A rapid and sensitive diagnosis of typhoid fever based on nested PCR-voltammetric DNA biosensor using flagellin gene fragment. Indonesian Journal of Chemistry. 16(1):87-91.

Issa, R., Hamdan, N.A. \& Noh, M.F.M. (2010). Differential pulse voltammetric determination of DNA hybridization using methylene blue on screen printed carbon electrode for The detection of Mycobacterium tuberculosis. Biotechnology. 9(3): 304-311.

Jin, H., Wei, M. \& Wang, J. (2013). Electrochemical DNA biosensor based on the BDD nanograss array electrode. Chemistry Central Journal. 7(1): 65-71.

Kaewphinit, T., Santiwatanakul, S., Promptmas, C. \& Chansiri, K. (2010). Detection of non-amplified mycobacterium tuberculosis genomic DNAbased biosensors. Sensors. 10(3): 1846-1858

Kardival, G.V., Kameswaran, M. \& Ray, M.K. (2000). Radioimmunoassay antibody detection in pulmonary tuberculosis. Indian Journal of Tuberculosis. 47(2): 97-100.

Nurmalasari, R., Yohan, Gaffar, S., Hartati, Y.W. (2015). Label-Free Electrochemical DNA biosensor for the detection of Mycobacterium tuberculosis using gold electrode modified by self-assembled monolayer of thiol. Procedia Chemistry. 17: 111-117
Reyes, C.M.A., Sanchez, L., Ong-Lim, A.L. \& Gonzales, M.L.M. (2011). A paired comparison of tuberculin skin test result in children with clinical manisfestations of tuberculosis using 2 TU and 5 TU tuberculins. PIDSP Journal. 12(2): 56-66

Sangeetha, P. \& Juliet, A.V. (2014). Simulation and analysis of mikro cantilever sensor for enhanced biosensing of desease of causing pathogens. International Journal of Engineering Development and Research. 5(1): 131-136.

Stavri, H., Bucurenci, N., Ulea, I., Costache, A., Popa, L., Popa, M.I. (2012). Use of recombinant purified protein derivative (PPD) antigens as specific skin test for tuberculosis. Indian Journal of Medical Research. 136(5): 799-807.

Wang, J., Cai, X., Rivas, G., Shiraishi, H. \& Dontha, N. (1997). Nucleic-acid immobilization, recognition and detection at chronopotentiometric DNA chips. Biosensors and Bioelectronics. 12(7): 587-599.

Yean, C.Y., Kamarudin, B., Ozkan, D.A., Yin, L.S., Lalitha, P., Ismail, A., Ozsoz, M. \& Ravichandran, M. (2008). Enzyme-linked amperometric electrochemical genosensor assay for detection of PCR amplicon on a streptavidin-treated screen printed carbon electrode. Analytical Chemistry. 80(8): 27742779.

Zhou, L., He, X., He, D., Wang, K. \& Qin, D. (2011). Biosensing Technologies for mycobacterium tuberculosis detection: Status and new developments. Clinical and Developmental Immunology. 2011: 193963. 